\title{
Effect of foliar application of humic substances on qualitative and quantitative traits of the yield of potato (Solanum tuberosum L.) and sugar beet (Beta vulgaris L.)
}

\author{
Wpływ nalistnej aplikacji substancji huminowych na cechy jakościowe \\ i ilościowe plonu ziemniaka (Solanum tuberosum L.) \\ i buraka cukrowego (Beta vulgaris L.)
}

\author{
Kinga Matysiak*
}

\begin{abstract}
Summary
Humic substances have a direct and indirect impact on plants and the environment. They stimulate the growth and development of plants, affect their metabolism, but also improve the chemical, physical and biological properties of soil, however their action is dependent on the dose and concentration. The aim of the study was to evaluate the impact of humic substances (HumiPlant) on qualitative and quantitative characteristics of potato and sugar beet crops, depending on the dose and development phase of the plants during the substance application. The field studies were carried out in Institute of Plant Protection - National Research Institute in the years 2011-2012. For each cultivated plant two separate double-agent experiments were established. The studies testes HumiPlant containing humic substances (humic and fulvic acids). The experiments evaluated tuber size, starch content in tubers and tuber yield (potato), as well as content of sodium, potassium and alpha-amino nitrogen, polarization and root yield (sugar beet).
\end{abstract}

Key words: humic acids, potato tuber size, polarization, natural alkalinity coefficient, sugar beet root yield

\section{Streszczenie}

Substancje huminowe mają pośredni i bezpośredni wpływ na rośliny i środowisko. Stymulują wzrost i rozwój roślin, wpływają na ich metabolizm, ale także poprawiają chemiczne, fizyczne i biologiczne właściwości gleby, jednak ich działanie jest ściśle zależne od dawki i stężenia. Celem badań była ocena substancji huminowych (HumiPlant) na cechy jakościowe i ilościowe plonu ziemniaka i buraka cukrowego w zależności od dawki i fazy rozwojowej rośliny uprawnej w czasie aplikacji preparatu. Badania polowe prowadzono w Instytucie Ochrony Roślin - Państwowym Instytucie Badawczym w latach 2011-2012. Dla każdej rośliny uprawnej założono dwa odrębne dwuczynnikowe doświadczenia. W doświadczeniach badano preparat HumiPlant zawierający substancje huminowe (kwasy huminowe i fulwowe). W doświadczeniach oceniano wielkość bulw, zawartość skrobi w bulwach i plon bulw (ziemniak) oraz zawartość sodu, potasu i azotu alfa-aminowego, polaryzację i plon korzeni (burak).

Słowa kluczowe: kwasy huminowe i fulwowe, wielkość bulw ziemniaka, polaryzacja, współczynnik alkaliczności naturalnej, plon korzeni buraka cukrowego

\footnotetext{
Instytut Ochrony Roslin - Państwowy Instytut Badawczy Władysława Węgorka 20, 60-318 Poznań

*corresponding author: k.matysiak@iorpib.poznan.pl

ORCID: 0000-0001-8082-9342
} 


\section{Wstęp / Introduction}

Jednym z najważniejszych czynników intensyfikacji produkcji roślinnej, mających wpływ na wydajność i jakość plonu jest nawożenie. Nawozy organiczne zawierają materię organiczną i obejmują różnorodną grupę materiałów. W wielu uprawach, jako nawóz organiczny z dużym powodzeniem wykorzystuje się obornik. Jednakże w ostatnich latach obserwuje się spadek produkcji tego nawozu, co prowadzi do poszukiwania alternatywnych, w tym ekologicznych rozwiązań (Boligłowa i Gleń 2003; Abu-Zinada i Sekh-Eleid 2015). Coraz bardziej znaczącą rolę w nawożeniu roślin odgrywają substancje huminowe - naturalne produkty organiczne obecne w próchnicy glebowej, które mają wpływ na biologiczne procesy całych ekosystemów (Chen i wsp. 2004). Podstawowymi składnikami humusu są kwasy huminowe i fulwowe, które poprawiają żyzność gleby i intensyfikują wymianę kationów przekształcając pierwiastki mineralne $\mathrm{w}$ formy dostępne dla roślin. W efekcie, substancje huminowe prowadzą do większego pobierania składników odżywczych przez korzenie. Substancje huminowe neutralizują $\mathrm{pH}$ gleby, umożliwiając roślinom także dostęp do pierwiastków śladowych zawartych w podłożu, ale również usuwają lub zmniejszają negatywny wpływ nawozów chemicznych z gleby. Szacuje się, że w próchnicy znajduje się od 65 do 70\% substancji huminowych. Głównymi frakcjami substancji huminowych, a zarazem najbardziej aktywnymi składnikami gleby i kompostu materii organicznej są kwasy huminowe. Posiadają wysoką masę cząsteczkową, występują w barwie od żółtej do czarnej, a dzięki grupom chelatowym charakteryzuje je powolny rozkład i uwalniane są do gleby sukcesywnie (Arancon i wsp. 2006; Mosa 2012; Yakhin i wsp. 2017).

Badania dowodzą, że substancje huminowe wywierają pośredni i bezpośredni wpływ na rośliny, choć ich działanie jest ściśle zależne od dawki i stężenia. Mechanizm działania substancji humusowych na stymulację wzrostu roślin nie jest całkowicie znany, ale niektórzy badacze uważają, że substancje huminowe zwiększają przepuszczalność błony komórkowej, pobieranie tlenu, mają wpływ na oddychanie i fotosyntezę oraz aktywność enzymatyczną. Efektem tego jest intensyfikacja wydłużania i podziałów komórek pędu i korzeni (Chen i wsp. 2004; Knapik 2018).

Uznaje się, że substancje huminowe są całkowicie bezpieczne dla organizmów żywych i środowiska. Można je ekstrahować z naturalnie nawilżonej materii organicznej (np. z torfu lub gleby wulkanicznej), z kompostów i wermikompostów lub ze złóż mineralnych (leonardyt, forma utleniająca lignitu) i stosować bezpośrednio na liście roślin w postaci płynnej lub bezpośrednio do gleby w postaci granulek lub roztworu (du Jardin 2015; Osman i wsp. 2013). Substancje huminowe mają więc pośredni (poprawa chemicznych, fizycznych i biologicznych właściwości gleby oraz odkażanie gleby) i bezpośredni (wpływ na metabo- lizm, stymulacja rozwoju) wpływ na rośliny i środowisko. Mogą poprawiać plonowanie roślin poprzez zwiększenie stanu odżywienia roślin, poprawę odporności na stres i stymulowanie różnych szlaków metabolicznych (Dobrzański i wsp. 2008; Rizk i wsp. 2013; Suh i wsp. 2014). Stosowanie substancji huminowych pozwala na ograniczanie zużycia syntetycznych chemikaliów, są więc cenną alternatywą dla bezpieczeństwa środowiska rolniczego. Dodatkowym atutem są niskie koszty ich pozyskiwania, niskie koszty stosowania, łatwa dostępność i brak niekorzystnego wpływu na środowisko. Korzystne działanie substancji huminowych na wzrost, rozwój i plonowanie zostało potwierdzone m.in. w uprawie kukurydzy (Sharif i wsp. 2002; Eyheraguibel i wsp. 2008; Matysiak i wsp. 2011), pomidora i ogórka (Atiyeh i wsp. 2002), pszenicy (Malik i Azam 1985), bobu (Akinci i wsp. 2009) i rzepaku (Matysiak i wsp. 2010).

Hipoteza badawcza zakładała, że nalistne stosowanie substancji huminowych na rośliny ziemniaka i buraka cukrowego ma pozytywny wpływ na plonowanie tych roślin, a uzyskane plony charakteryzują się wyższą jakością. W badaniach założono także, iż czynnikami decydującymi o wpływie substancji huminowych na cechy ilościowe i jakościowe plonu ziemniaka i buraka cukrowego są jednocześnie faza rozwojowa rośliny uprawnej w momencie zabiegu oraz ilość zastosowanych substancji huminowych (dawka preparatu HumiPlant).

Celem badań była ocena substancji huminowych $(\mathrm{Hu}-$ miPlant) na cechy jakościowe i ilościowe plonu ziemniaka i buraka cukrowego w zależności od dawki i fazy rozwojowej rośliny uprawnej w czasie aplikacji preparatu.

\section{Materiały i metody / Materials and methods}

Badania prowadzono w latach 2011-2012, w Polowej Stacji Doświadczalnej w Winnej Górze (52¹2’N, $\left.17^{\circ} 27^{\circ} \mathrm{E}\right)$, należącej do Instytutu Ochrony Roślin - Państwowego Instytutu Badawczego w Poznaniu. Do doświadczeń wybrano buraka cukrowego odmiany Soplica oraz ziemniaka odmiany Tajfun. Doświadczenia założono w 4 powtórzeniach, w układzie split-plot, na glebie bielicowej, o pH 5,3-5,8 w zależności od roku doświadczalnego. Powierzchnia poletka doświadczalnego wynosiła $33 \mathrm{~m}^{2}$ dla ziemniaka i $30 \mathrm{~m}^{2}$ dla buraka cukrowego (szerokość międzyrzędzi $45 \mathrm{~cm})$. W roku badawczym 2011 przedplon stanowiło pszenżyto ozime, w roku 2012 dla buraka cukrowego - kukurydza, a dla ziemianka pszenica ozima. Planowane obsady badanych roślin uprawnych wynosiły: 80 tys. roślin/ha dla buraka cukrowego i 35 tys. roślin/ha dla ziemniaka. $\mathrm{W}$ doświadczeniu z ziemniakiem zastosowano Amofosmag w dawce $350 \mathrm{~kg} / \mathrm{ha}$, saletrę amonową 34\% w dawce $100 \mathrm{~kg} / \mathrm{ha}$ i mocznik 46\% w dawce $170 \mathrm{~kg} / \mathrm{ha}$. W doświadczeniu z burakiem cukrowym stosowano Amofosmag w dawce $400 \mathrm{~kg} / \mathrm{ha}$ i saletrę amonową 34\% w dawce 
$176 \mathrm{~kg} / \mathrm{ha}$. W doświadczeniach zastosowano standardową ochronę herbicydową i fungicydową.

Substancje huminowe aplikowano nalistnie w postaci preparatu HumiPlant będącego wodną zawiesiną zawierającą 12\% kwasów huminowych i 6\% kwasów fulwowych w postaci soli potasowych i $0,01 \%$ boru w postaci boranów. Preparat stosowano jedno-, dwu- i trzykrotnie (w terminach T1, T2 i T3), rozpoczynając od fazy BBCH 15 rośliny uprawnej, a następnie w odstępach 14 dni. HumiPlant badano w dwóch dawkach: 3,0 1/ha i 5,0 1/ha. Zabiegi wykonano za pomocą opryskiwacza plecakowego Gloria, zaopatrzonego w rozpylacze typu Tee-Jet 11003 XR (4 szt.), umieszczone w odległości $50 \mathrm{~cm}$ na belce opryskiwacza. Do wykonania zabiegów zastosowano 200 litrów wody na ha, przy ciśnieniu $0,3 \mathrm{hPa}$.

W doświadczeniu z ziemniakiem określono zawartość skrobi w bulwach, plon bulw oraz wielkość bulw, dzieląc je na frakcje: a) bulwy o średnicy mniejszej niż $4 \mathrm{~cm}$, b) bulwy o średnicy 4-6 cm, c) bulwy o średnicy większej niż $6 \mathrm{~cm}$. Wielkość próby wynosiła około $5 \mathrm{~kg}$. W doświadczeniu z burakiem cukrowym oceniano plon korzeni, zawartość cukru, zawartość potasu, sodu i azotu alfa-aminowego. Analizę chemiczną korzeni buraka przeprowadzono w Cukrowni Środa Sp. z o.o. W oparciu o dokonane analizy wyliczono wskaźnik alkaliczności naturalnej według wzoru podanego przez Bzowską-Bakalarz i Banacha (2009):

$$
\mathrm{WA}=\mathrm{K}+\mathrm{Na} / \mathrm{N}-\alpha
$$

gdzie: K, Na, N- $\alpha$ - zawartość składników w mmol/1000 g miazgi

Wyniki poddano analizie wariancji z wykorzystaniem programu FR ANALWAR 5.2 dla doświadczenia dwuczynnikowego. Istotne różnice (NIR) wyznaczano za pomocą testu Tukeya przy poziomie istotności $\mathrm{p} \leq 0,05$.

\section{Wyniki i dyskusja / Results and discussion}

Oceniając wielkość bulw ziemianka zaobserwowano, że największy udział miała frakcja bulw średnich (średnica 4-6 cm) i wynosiła w zależności od kombinacji doświadczalnej od 51 do $65 \%$ wszystkich bulw (tab. 1). Jednakże bulwy z obiektów, gdzie stosowano dwu- lub trzykrotnie substancje huminowe były większe, niż na obiekcie kontrolnym. W doświadczeniu uzyskano zwiększenie frakcji bulw dużych o 24 do 44\%, przy czym największy wzrost odnotowano w próbie pobranej z poletek, gdzie HumiPlant aplikowany był trzykrotnie w najwyższych dawkach. Tam też uzyskano najmniejszą frakcję bulw małych (średnica poniżej $6 \mathrm{~cm}$ ). Zwiększenie w plonie udziału bulw dużych pod wpływem nalistnej aplikacji substancji huminowych (kwasów huminowych i kwasów fulwowych) potwierdzają w swoich badaniach Rizk i wsp. (2013) oraz Suh i wsp. (2014), którzy zwracają jednak uwagę na brak wpływu tych substancji na plon ogólny ziemniaka.

Analizując zawartość skrobi w bulwach zanotowano, iż istotne różnice w stosunku do kontroli, polegające na zwiększeniu jej zawartości w bulwach dotyczyły obiektów, na których stosowano preparat dwukrotnie lub trzykrotnie w dawce 5 1/ha (tab. 2). Uzyskano wzrost zawartości skrobi o $27-30 \%$. W pozostałych obiektach doświadczalnych zaobserwowano także tendencję do zwiększania zawartości skrobi w bulwach, a pomiędzy obiektami, na których stosowano HumiPlant w różnych dawkach i terminach nie odnotowano istotnych różnic dla tej cechy. Pozytywny wpływ substancji huminowych na zwiększanie zawartości skrobi w bulwach ziemniaka potwierdza także Mystkowska (2019). W przeprowadzonych doświadczeniach nie odnotowano istotnego wpływu substancji huminowych na plon bulw ziemniaka (tab. 2). Tymczasem Sanli i wsp. (2013) stosując

Tabela 1. Udział frakcji bulw ziemniaka

Table 1. Potato tubers' contribution in fraction groups

\begin{tabular}{|c|c|c|c|c|c|c|c|c|}
\hline \multirow{3}{*}{$\begin{array}{l}\text { Lp. } \\
\text { No. }\end{array}$} & \multirow{3}{*}{$\begin{array}{l}\text { Obiekt - Treatment } \\
\text { Termin zabiegu } \\
\text { Term of application }\end{array}$} & \multirow{3}{*}{$\begin{array}{c}\text { Dawka } \\
\text { Dose } \\
{[1 / \mathrm{ha}]}\end{array}$} & \multicolumn{6}{|c|}{$\begin{array}{l}\text { Frakcja bulw ziemniaka } \\
\text { Potato tubers' contribution in fraction groups }\end{array}$} \\
\hline & & & \multicolumn{2}{|c|}{$\varnothing>6 \mathrm{~cm}$} & \multicolumn{2}{|c|}{$\varnothing=4-6 \mathrm{~cm}$} & \multicolumn{2}{|c|}{$\varnothing<6 \mathrm{~cm}$} \\
\hline & & & $\begin{array}{l}\% \text { udziału } \\
\% \text { of contri- } \\
\text { bution }\end{array}$ & $\begin{array}{l}\% \text { kontroli } \\
\% \text { to control }\end{array}$ & $\begin{array}{l}\% \text { udziału } \\
\% \text { of contri- } \\
\text { bution }\end{array}$ & $\begin{array}{c}\% \text { kontroli } \\
\% \text { to control }\end{array}$ & $\begin{array}{c}\% \text { udziału } \\
\% \text { of contri- } \\
\text { bution }\end{array}$ & $\begin{array}{l}\% \text { kontroli } \\
\% \text { to control }\end{array}$ \\
\hline 1. & kontrola - control & - & 18,2 & 100 & 51,3 & 100 & 30,5 & 100 \\
\hline 2. & HumiPlant T1 & 3 & 17,9 & 98 & 55,7 & 109 & 26,4 & 87 \\
\hline 3. & HumiPlant T1 & 5 & 18,7 & 103 & 60,3 & 118 & 21,0 & 69 \\
\hline 4. & HumiPlant T1/T2 & $3 / 3$ & 22,5 & 124 & 62,1 & 121 & 15,4 & 50 \\
\hline 5. & HumiPlant T1/T2 & $5 / 5$ & 24,4 & 134 & 62,9 & 123 & 12,7 & 42 \\
\hline 6. & HumiPlant T1/T2/T3 & $3 / 3 / 3$ & 26,1 & 143 & 64,9 & 127 & 9,0 & 30 \\
\hline 7. & HumiPlant T1/T2/T3 & $5 / 5 / 5$ & 25,9 & 144 & 64,3 & 125 & 9,8 & 32 \\
\hline
\end{tabular}

$\mathrm{T} 1-\mathrm{BBCH} 15, \mathrm{~T} 2-14$ dni po $\mathrm{T} 1-14$ days after T1, T3 - 14 dni po T2 - 14 days after T2 
substancje huminowe uzyskali znaczny wzrost plonu bulw wynoszący do $27 \% \mathrm{w}$ porównaniu z kontrolą, przy czym czynnikiem warunkującym uzyskanie wysokich plonów była ilość zastosowanych substancji huminowych. Zarzecka i Gugała (2012) stosując koncentrat nawozowy UGmax, który wpływa na poprawę struktury gleby, uzyskali po aplikacji doglebowej i nalistnej wzrost plonu bulw ziemniaka o 30\%, a Jabłoński (2009) wzrost plonu ogólnego o 12\%. Mystkowska (2017) w swoich badaniach udowodniła, że nalistne zastosowanie preparatu zawierającego substancje huminowe może zwiększyć plon bulw ziemniaka o $28 \%$. Mystkowska (2018) zwraca uwagę, że czynnikiem mody- fikującym działanie substancji huminowych na plonowanie ziemniaka, oprócz czynnika odmianowego, są warunki pogodowe.

W doświadczeniach $\mathrm{z}$ burakiem cukrowym oceniano zawartość sodu, potasu i azotu alfa-aminowego w korzeniach (tab. 3). Jak podaje Stępień i wsp. (2010) jakość plonów korzeni buraka cukrowego w dużym stopniu zależy od zawartości niecukrów szkodliwych (azot $\alpha$-aminowy, sód i potas), w skład których wchodzą tzw. popioły rozpuszczalne. Zbyt duża ich obecność w korzeniach znacznie obniża wydatek cukru technologicznego. W przeprowadzonych badaniach nie stwierdzo-

Tabela 2. Zawartość skrobi w bulwach i plon bulw ziemniaka

Table 2. Content of starch in potato tubers and yield of potato

\begin{tabular}{|c|c|c|c|c|c|c|}
\hline \multirow{2}{*}{$\begin{array}{l}\text { Lp. } \\
\text { No. }\end{array}$} & \multirow{2}{*}{$\begin{array}{l}\text { Obiekt }- \text { Treatment } \\
\text { Termin zabiegu } \\
\text { Term of application }\end{array}$} & \multirow{2}{*}{$\begin{array}{l}\text { Dawka } \\
\text { Dose } \\
{[1 / \text { ha }]}\end{array}$} & \multicolumn{2}{|c|}{$\begin{array}{l}\text { Zawartość skrobi w bulwach } \\
\text { Starch content in tubers }\end{array}$} & \multicolumn{2}{|c|}{ Plon - Yield } \\
\hline & & & {$[\%]$} & $\begin{array}{c}\% \text { kontroli } \\
\% \text { to control }\end{array}$ & {$[\mathrm{t} / \mathrm{ha}]$} & $\begin{array}{c}\% \text { kontroli } \\
\% \text { to control }\end{array}$ \\
\hline 1. & kontrola - control & - & 13,5 & 100 & 35,4 & 100 \\
\hline 2. & HumiPlant T1 & 3 & 14,1 & 104 & 35,9 & 101 \\
\hline 3. & HumiPlant T1 & 5 & 15,5 & 115 & 36,1 & 102 \\
\hline 4. & HumiPlant T1/T2 & $3 / 3$ & 16,7 & 124 & 35,7 & 101 \\
\hline 5. & HumiPlant T1/T2 & $5 / 5$ & $17,1^{*}$ & $127^{*}$ & 36,4 & 103 \\
\hline 6. & HumiPlant T1/T2/T3 & $3 / 3 / 3$ & 16,9 & 125 & 36,9 & 104 \\
\hline 7. & HumiPlant T1/T2/T3 & $5 / 5 / 5$ & $17,5^{*}$ & $130 *$ & 36,7 & 104 \\
\hline \multicolumn{3}{|c|}{$\operatorname{NIR}(0,05)-\operatorname{LSD}(0.05)$} & \multicolumn{2}{|c|}{3,46} & \multicolumn{2}{|c|}{$\mathrm{ni}-\mathrm{ns}$} \\
\hline
\end{tabular}

T1 - BBCH 15, T2 - 14 dni po T1 - 14 days after T1, T3 - 14 dni po T2 - 14 days after T2

ni - różnice nieistotne - ns - not significant differences

* - różnice istotne - significant differences

Tabela 3. Zawartość sodu, azotu $\alpha$-aminowego i potasu w korzeniach buraka cukrowego

Table 3. Content of potassium, $\mathrm{N}-\alpha$-amin, $\mathrm{Na}$ in sugar beet roots

\begin{tabular}{|c|c|c|c|c|c|c|c|c|}
\hline \multirow{3}{*}{$\begin{array}{l}\text { Lp. } \\
\text { No. }\end{array}$} & \multirow{3}{*}{$\begin{array}{l}\text { Obiekt - Treatment } \\
\text { Termin zabiegu } \\
\text { Term of application }\end{array}$} & \multirow{3}{*}{$\begin{array}{l}\text { Dawka } \\
\text { Dose } \\
{[1 / \mathrm{ha}]}\end{array}$} & \multicolumn{6}{|c|}{$\begin{array}{l}\text { Zawartość makroelementów w korzeniach buraka } \\
\text { Content of macronutrients in sugar beet roots }\end{array}$} \\
\hline & & & \multicolumn{2}{|l|}{ K } & \multicolumn{2}{|c|}{$\mathrm{N}-\alpha$-amin } & \multicolumn{2}{|l|}{$\mathrm{Na}$} \\
\hline & & & {$[\mathrm{mmol} / 1000 \mathrm{~g}]$} & $\begin{array}{c}\% \text { kontroli } \\
\% \text { to control }\end{array}$ & {$[\mathrm{mmol} / 1000 \mathrm{~g}]$} & $\begin{array}{c}\% \text { kontroli } \\
\% \text { to control }\end{array}$ & {$[\mathrm{mmol} / 1000 \mathrm{~g}]$} & $\begin{array}{c}\% \text { kontroli } \\
\% \text { to control }\end{array}$ \\
\hline 1. & kontrola - control & - & 45,8 & 100 & 25,1 & 100 & 3,6 & 100 \\
\hline 2. & HumiPlant T1 & 3 & 45,2 & 99 & 22,2 & 88 & 4,0 & 111 \\
\hline 3. & HumiPlant T1 & 5 & 45,8 & 100 & 23,6 & 94 & 3,5 & 97 \\
\hline 4. & HumiPlant T1/T2 & $3 / 3$ & 42,3 & 92 & 19,9 & 80 & 3,7 & 103 \\
\hline 5. & HumiPlant T1/T2 & $5 / 5$ & 43,1 & 94 & 18,9 & $75^{*}$ & 4,1 & 114 \\
\hline 6. & HumiPlant T1/T2/T3 & $3 / 3 / 3$ & 42,6 & 93 & 18,1 & $72 *$ & 3,8 & 105 \\
\hline 7. & HumiPlant T1/T2/T3 & $5 / 5 / 5$ & 41,2 & 90 & 17,4 & $70^{*}$ & 4,1 & 114 \\
\hline \multicolumn{3}{|c|}{ NIR $(0,05)-\operatorname{LSD}(0.05)$} & \multicolumn{2}{|c|}{$\mathrm{ni}-\mathrm{ns}$} & \multicolumn{2}{|c|}{5,13} & \multicolumn{2}{|c|}{$\mathrm{ni}-\mathrm{ns}$} \\
\hline
\end{tabular}

T1 - BBCH 15, T2 - 14 dni po T1 - 14 days after T1, T3 - 14 dni po T2 - 14 days after T2

ni - różnice nieistotne - ns - not significant differences

* - różnice istotne - significant differences 
Tabela 4. Polaryzacja, współczynnik alkaliczności naturalnej oraz plon korzeni buraka cukrowego Table 4. Polarization alkalinity coefficient and yield of sugar beet roots

\begin{tabular}{|c|c|c|c|c|c|c|c|c|}
\hline \multirow[t]{2}{*}{$\begin{array}{l}\text { Lp. } \\
\text { No. }\end{array}$} & \multirow{2}{*}{$\begin{array}{l}\text { Obiekt }- \text { Treatment } \\
\text { Termin zabiegu } \\
\text { Term of application }\end{array}$} & \multirow{2}{*}{$\begin{array}{l}\text { Dawka } \\
\text { Dose } \\
{[1 / \text { ha }]}\end{array}$} & \multicolumn{2}{|c|}{$\begin{array}{l}\text { Polaryzacja } \\
\text { Polarization }\end{array}$} & \multicolumn{2}{|c|}{$\begin{array}{c}\text { Współczynnik } \\
\text { alkaliczności naturalnej } \\
\text { Natural alkalinity } \\
\text { coefficient }\end{array}$} & \multicolumn{2}{|c|}{$\begin{array}{l}\text { Plon korzeni } \\
\text { buraka cukrowego } \\
\text { Yield of sugar } \\
\text { beet roots }\end{array}$} \\
\hline & & & {$[\%]$} & $\begin{array}{l}\% \text { kontroli } \\
\% \text { to control }\end{array}$ & $\begin{array}{l}\text { wartość } \\
\text { value }\end{array}$ & $\begin{array}{c}\% \text { kontroli } \\
\% \text { to control }\end{array}$ & {$[\mathrm{t} / \mathrm{ha}]$} & $\begin{array}{l}\% \text { kontroli } \\
\% \text { to control }\end{array}$ \\
\hline 1. & kontrola - control & - & 18,3 & 100 & 1,97 & 100 & 49,7 & 100 \\
\hline 2. & HumiPlant T1 & 3 & 18,2 & 99 & 2,22 & 113 & 51,4 & 103 \\
\hline 3. & HumiPlant T1 & 5 & 18,8 & 103 & 2,09 & 106 & 50,1 & 101 \\
\hline 4. & HumiPlant T1/T2 & $3 / 3$ & 18,3 & 100 & $2,31 *$ & $117^{*}$ & 52,7 & 106 \\
\hline 5. & HumiPlant T1/T2 & $5 / 5$ & 18,2 & 99 & $2,49 *$ & $126^{*}$ & 55,7 & 112 \\
\hline 6. & HumiPlant T1/T2/T3 & $3 / 3 / 3$ & 18,1 & 99 & $2,56^{*}$ & $130^{*}$ & $56,9 *$ & $114^{*}$ \\
\hline 7. & HumiPlant T1/T2/T3 & $5 / 5 / 5$ & 18,2 & 99 & $2,60 *$ & $132 *$ & $56,4^{*}$ & $113^{*}$ \\
\hline \multicolumn{3}{|c|}{$\operatorname{NIR}(0,05)-\operatorname{LSD}(0.05)$} & \multicolumn{2}{|c|}{$\mathrm{ni}-\mathrm{ns}$} & \multicolumn{2}{|c|}{0,342} & \multicolumn{2}{|c|}{6,15} \\
\hline
\end{tabular}

T1 - BBCH 15, T2 - 14 dni po T1 - 14 days after T1, T3 - 14 dni po T2 - 14 days after T2

$\mathrm{ni}$ - różnice nieistotne - ns - not significant difference

* - różnice istotne - significant differences

no istotnych różnic w zawartości potasu i sodu pomiędzy obiektem kontrolnym a obiektami, na których zastosowano preparat huminowy, aczkolwiek w przypadku potasu zaobserwowano tendencję do zmniejszania zawartości tego pierwiastka w korzeniach buraka pod wpływem badanego preparatu. Poziom azotu alfa-aminowego spadał pod wpływem działania substancji huminowych, a na obiektach, gdzie aplikowano HumiPlant dwukrotnie w dawce 5 1/ha lub trzykrotnie w dawkach 3 l/ha i 5 l/ha wystąpiły jego istotnie niższe wartości - poziom azotu alfa-aminowego obniżył się o 25 do $30 \%$. W przypadku zawartości sodu nie odnotowano istotnych różnic pomiędzy obiektami doświadczalnymi. HumiPlant nie wpłynął również istotnie na zawartość cukru w korzeniach buraka (tab. 4). Brak wpływu substancji huminowych na zawartość cukru w korzeniach buraka potwierdza także Wilczewski i wsp. (2018).

W doświadczeniach uzyskano także istotny wpływ preparatu huminowego na współczynnik alkaliczności naturalnej. Dwu- lub trzykrotne zastosowanie preparatu HumiPlant zwiększyło wartość współczynnika o 17-32\%, przy czym najwyższą wartość uzyskano w kombinacji, w której preparat aplikowano trzykrotnie w dawce 5 1/ha. Dane literaturowe potwierdzają, że współczynnik alkaliczności naturalnej jest istotnym wskaźnikiem jakości korzeni, który w dojrzałych i prawidłowo nawożonych burakach cukrowych powinien być równy lub większy od 1,8. Zbyt niski współczynnik alkaliczności zmusza do alkalizowania soków buraczanych, co pociąga za sobą zwiększanie strat cukru w melasie (Bzowska-Bakalarz i Banach 2009). W przeprowadzonych doświadczeniach po aplikacji preparatu HumiPlant uzyskano współczynnik alkaliczności naturalnej o wartościach od 2,22 do 2,56 w zależności od częstotliwości i dawki stosowanego preparatu. Zdaniem Bzowskiej-Bakalarz i Banacha (2009) zbyt wysokie wartości współczynnika alkaliczności, przekraczające wartość 2,3 stwarzają trudności technologiczne podczas ekstrakcji cukru.

W doświadczeniach potwierdzono również korzystne działania preparatu huminowego na plonowanie buraka cukrowego (tab. 4). Trzykrotne zastosowanie preparatu huminowego zwiększyło plon korzeni o $13-14 \%$ w stosunku do kontroli, przy czym nie odnotowano różnicy pomiędzy dawką 3 1/ha i 5 1/ha. Plon korzeni uzyskany z pozostałych obiektów, na których aplikowano HumiPlant nie różnił się istotnie od plonu uzyskanego z obiektu kontrolnego. Pozytywny wpływ substancji huminowych na plon korzeni buraka cukrowego znajduje potwierdzenie w badaniach Wilczewskiego i wsp. (2018), którzy po jednokrotnej, przedsiewnej aplikacji preparatu Humistar uzyskali w stosunku do obiektu kontrolnego wzrost plonu o 2,4 t/ha.

\section{Wnioski / Conclusions}

1. Wielkość bulw ziemniaka zależała od częstości aplikacji i dawki preparatu HumiPlant. Najkorzystniejszą kombinacją dla tej cechy była ta, gdzie preparat HumiPlant stosowano trzykrotnie (co 14 dni zaczynając od fazy BBCH 15) w najwyższej dawce 5 1/ha.

2. Dwu- lub trzykrotne zastosowanie preparatu HumiPlant w najwyższej dawce $(5$ l/ha) zwiększało zawartość 
skrobi w bulwach, jednak badany preparat nie wpływał istotnie na plon bulw ziemniaka.

3. HumiPlant nie miał wpływu na zawartość sodu i potasu, ale dwukrotne stosowanie preparatu w dawce $51 /$ ha oraz trzykrotne (zarówno 3 1/ha, jak i 5 1/ha) znacząco obniżało zawartość azotu alfa-aminowego w korzeniach buraka cukrowego oraz podwyższało wartość współczynnika alkaliczności naturalnej.

4. Preparat HumiPlant nie miał wpływu na poziom cukru w korzeniach, a wzrost plonu korzeni wystąpił wyłącznie po trzykrotnym zastosowaniu badanego preparatu, zarówno w dawce 3 1/ha, jak i 5 1/ha.

\section{Literatura / References}

Abu-Zinada I.A., Sekh-Eleid K.S. 2015. Humic acid to decrease fertilization rate on potato (Solanum tuberosum L.). American Journal of Agriculture and Forestry 3 (5): 234-238. DOI: 10.11648/j.ajaf.20150305.20

Akinci S., Bueyuekkeskin T., Eroğlu A., Erdoğan B.E. 2009. The effect of humic acid on nutrient composition in broad bean (Vicia faba L.) roots. Notulae Scientia Biologicae 1 (1): 81-87.

Arancon N.Q., Edwards C.A., Lee S., Byrne R. 2006. Effects of humic acids from vermicomposts on plant growth. European Journal of Soil Biology 42: S65-S69. DOI: 10.1016/j.ejsobi.2006.06.004

Atiyeh R.M., Lee S., Edwards C.A., Arancon N.Q., Metzger J.D. 2002. The influence of humic acids derived from earthworm-processed organic wastes on plant growth. Bioresource Technology 84 (1): 7-14. DOI: 10.1016/s0960-8524(02)00017-2

Boligłowa E., Gleń K. 2003. Yielding and quality of potato tubers depending on the kind of organic fertilization and tillage method. Electronic Journal of Polish Agricultural Universities 6 (1): 1-8.

Bzowska-Bakalarz M., Banach M. 2009. Właściwości technologiczne surowca buraczanego produkowanego w zmodyfikowanej technologii nawożenia. [Technological properties of sugar beet produced in modified fertilisation technology]. Acta Agrophysica 14 (1): 31-40.

Chen Y., Clapp C.E., Magen H. 2004. Mechanisms of plant growth stimulation by humic substances: The role of organo-iron complexes. Soil Science and Plant Nutrition 50 (7): 1089-1095. DOI: 10.1080/00380768.2004.10408579

Dobrzański A., Anyszka Z., Elkner K. 2008. Reakcja marchwi na ekstrakty pochodzenia naturalnego z alg z rodzaju Sargassum Algaminoplant i z leonardytu - HumiPlant. [Response of carrots to application of natural extracts from seaweed (Sargassum sp.) - Algaminoplant and from leonardite - HumiPlant]. Journal of Research and Applications in Agricultural Engineering 53 (3): 53-58.

du Jardin P. 2015. Plant biostimulants: definition, concept, main categories and regulation. Scientia Horticulturae 196: 3-14. DOI: 10.1016/j.scienta.2015.09.021

Eyheraguibel B., Silvestre J., Morard P. 2008. Effects of humic substances derived from organic waste enhancement on the growth and mineral nutrition of maize. Bioresource Technology 99 (10): 4206-4212. DOI: 10.1016/j.biortech.2007.08.082

Jabłoński K. 2009. Kierunki przewidywanych zmian w technologii produkcji ziemniaka do roku 2020. Studia i Raporty IUNG - PIB 17: $117-127$

Knapik M. 2018. Zastosowanie biostymulatorów we współczesnym rolnictwie. [Using biostimulants in modern agriculture]. Zeszyty Studenckiego Ruchu Naukowego Uniwersytetu Jana Kochanowskiego w Kielcach 27 (2): 79-84.

Malik K.A., Azam F. 1985. Effects of humic acid on wheat (Triticum aestivum L.) seedling growth. Environmental and Experimental Botany 25 (3): 245-252. DOI: 10.1016/0098-8472(85)90008-5

Matysiak K., Kaczmarek S., Kierzek R., Kardasz P. 2010. Effect of seaweeds extracts and humic and fulvic acids on the germination and early growth of winter oilseed rape (Brassica napus L.). [Ocena działania ekstraktów z alg morskich oraz mieszaniny kwasów huminowych i fulwowych na kiełkowanie i początkowy wzrost rzepaku ozimego (Brassica napus L.)]. Journal of Research and Applications in Agricultural Engineering 55 (4): 28-32.

Matysiak K., Kaczmarek S., Krawczyk R. 2011. Influence of seaweed extracts and mixture of humic and fluvic acids on germination and growth of Zea mays L. [Wpływ ekstraktów z alg morskich oraz kwasów huminowych i fulwowych na kiełkowanie i początkowy wzrost Zea mays L.]. Acta Scientiarum Polonorum, Agricultura 10 (1): 33-45.

Mosa A.A. 2012. Effect of the application of humic substances on yield, quality, and nutrient content of potato tubers in Egypt. s. 471-492. W: Sustainable Potato Production: Global Case Studies (Z. He, R. Larkin, W. Honeycutt, red.). Springer Netherlands, Dordrecht, 542 ss. ISBN 978-94-007-4103-4. DOI: 10.1007/978-94-007-4104-1

Mystkowska I. 2017. Wpływ zróżnicowanej techniki odchwaszczania i stosowania biostymulatorów na efektywność ekonomiczną uprawy ziemniaków jadalnych. [Effects of different weed control of techniques and biostimulators on economic efficiency of potaoes growing]. Roczniki Naukowe Stowarzyszenia Ekonomistów Rolnictwa i Agrobiznesu 19 (6): 190-193. DOI: 10.5604/01. 3001.0010 .7928

Mystkowska I. 2018. Biostymulatory jako czynnik wpływający na plon ziemniaka jadalnego. [Biostimulators as a factor affecting the yield of edible potato]. Acta Agrophysica 25 (3): 307-315. DOI: $10.31545 /$ aagr/95109

Mystkowska I. 2019. Wpływ stosowania biostymulatorów na zawartość suchej masy i skrobi w bulwach ziemniaka jadalnego. [The effect of the use of biostimulators on dry matter and starch content of tuber potatoes]. Fragmenta Agronomica 36 (1): 45-53. DOI: 10.26374/ fa.2019.36.5

Osman E.A.M., El-Masry A.A., Khatab K.A. 2013. Effect of nitrogen fertilizer sources and foliar spray of humic and/or fulvic acids on yield and quality of rice plants. Advances in Applied Science Research 4 (4): 174-183.

Rizk F.A., Shaheen A.M., Singer S.M., Sawan O.A. 2013. The productivity of potato plants affected by urea fertilizer as foliar spraying and humic acid added with irrigation water. Middle East Journal of Agricultural Research 2 (2): 76-83.

Sanli A., Karadogan T., Tonguc M. 2013. Effects of leonardite applications on yield and some quality parameters of potatoes (Solanum tuberosum L.). Turkish Journal of Field Crops 18 (1): 20-26. 
Sharif M., Khattak R.A., Sarir M.S. 2002. Effect of different levels of lignitic coal derived humic acid on growth of maize plants. Soil Science and Plant Analysis 33 (19-20): 3567-3580. DOI: 10.1081/CSS-120015906

Stępień A., Pawluczuk J., Adamiak J., Marks M., Buczyński G. 2010. Wpływ wybranych czynników klimatycznych Polski północno-wschodniej na jakość plonu korzeni buraka cukrowego. [Influence of meteorological conditions in north-eastern poland on quality of sugar beet yields]. Fragmenta Agronomica 27 (1): 170-176.

Suh H.Y., Yoo K.S., Suh S.G. 2014. Tuber growth and quality of potato (Solanum tuberosum L.) as affected by foliar or soil application of fulvic and humic acids. Horticulture, Environment, and Biotechnology 55 (3): 183-189. DOI: 10.1007/s13580-014-0005-x

Wilczewski E., Szczepanek M., Wenda-Piesik A. 2018. Response of sugar beet to humic substances and foliar fertilization with potassium. [Reakcja buraka cukrowego na substancje humusowe i dolistne nawożenie potasem]. Journal of Central European Agriculture 19 (1): 153-165. DOI: 10.5513/JCEA01/19.1.2033

Yakhin O.I., Lubyanov A.A., Yakhin I.A., Brown P.H. 2017. Biostimulants in plant science: a global perspective. Frontiers in Plant Science 7: 2049. DOI: $10.3389 /$ fpls.2016.02049

Zarzecka K., Gugała M. 2012. Plonotwórcze działanie użyźniacza glebowego UGmax w prawie ziemniaka. [Crop-yielding effect of soil fertilizer UGmax in cultivation of potato]. Inżynieria Ekologiczna 28: 144-148. 